\author{
Zhanabayev $^{1}$ K., Turgenbayeva ${ }^{2}$ A.Sh., Islyamova U.A $A^{3}$ \\ ${ }^{1}$ Al-Farabi Kazakh national university, \\ ${ }^{2}$ Al-Farabi Kazakh national university, \\ ${ }^{3}$ Al-Farabi Kazakh national university,
}

Kazakhstan, Almaty, ovlur1963@mail.ru

\title{
CH.CH. VALIKHANOV ABOUT THE LANGUAGE AND STYLE OF THE TURKIC EPIC
}

\begin{abstract}
In this article consider about the scientific contribution of Ch.Ch. Valikhanov to the Turkic epic studies, about his study of the epic culture of the Turks of Central Asia, Southern Siberia and the North Caucasus. The main place in it is devoted to the language, style and genre of the epic of the Turkic peoples, their poetic forms and their art of speech.

The purpose of the article is to reveal the views and methodological approaches of the scientist in the light of the current oral theory of Parry-Lord, to identify their prospects and productivity.

The practical value of the article comes from the scientific effectiveness of the works and ideas of the scientist in his analysis of oral poetic forms of folklore, stylistics and aesthetics.

The main method of Ch.Ch. Valikhanov is holistic, that is, a view "from within the tradition itself" in its living process. This method did not exclude the comparative-historical, typological, systematic method, the method of analysis and revealed great prospects in the scientific study of the oral epic of the Turkic nations.

The main conclusion of this article is that the first professional orientalist, ethnographer, historian, linguist Ch.Ch. Valikhanov is the founder of classical Turkic epic studies, the first collector and original commentator of its best samples. He brilliantly foresaw many directions of modern topical oral theory and world folklore and deeply understood the unique nature of the ancient Steppe knowledge, the mighty oral epic of the Turks of the North Caucasus, Southern Siberia, Central and Central Asia. For the first time, this integral epic Turkic tradition is described by him in all the genre and species richness. The historical and ethnographic approach of the scientist to the analysis of the epic art of the Turkic peoples is of valuable practical importance for oral theory and the humanities.
\end{abstract}

Keywords: poetic form, oral Parry-Lord theory, tradition, formula style, Turkic epic, Steppe knowledge, initial foundations.

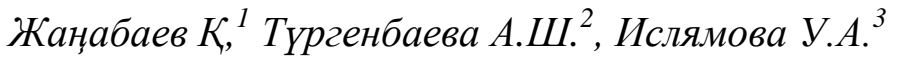

$$
\begin{aligned}
& { }^{1} Ә л \text {-Фараби атындавы Қазақ ұлттық университеті, } \\
& { }^{2} \text { Әл-Фараби атындавы Қазақ ұлттық университеті, } \\
& { }^{3} \text { Әл-Фараби атындавы Қазақ ұлттық университеті, }
\end{aligned}
$$

Қазақ̧стан, Алматы қ., ovlur1963@mail.ru

\section{Ш.Ш. УӘЛИХАНОВ ЖӘНЕ СӨЗ ӨНЕРІНІҢ АУЫЗША ТЕОРИЯСЫ}

\section{Андаmna}

Мақала Ш.Ш. Уәлихановты еске алуға және қазіргі мәдениетаралық коммуникация объектісі - ауызекі тіл теориясының өзекті мәселелеріне арналған. Онда жанр теориясы мен 
журналистика өнерін зерттейтін студенттерге қажет ауызша сөйлеу стилі мен жанры, ауызша-стилистикалық әдістер мен сөз өнері туралы мәселелері көтеріледі.

Мақаланың негізгі мақсаты - қазақ ауыз әдебиетінің тек жанрлық формаларының табиғатынан ғана емес, сонымен қатар онымен функционалды байланысты стилистика мен сөз өнерінің табиғатынан бастау алатын американдық жетекші зерттеушілердің - ПарриЛордтың ауызша теориясы аясында ғалым идеяларының өзектілігін анықтау.

Зерттеудің де, ғалымның еңбектерінің де әдіснамалық құндылығы фольклордың ауызша жанрлық формаларын, сөз стилистикасы мен өнерін талдауда және Ш.Ш. Уәлихановтың негізгі әдісін, оның "дәстүр ішіндегі" көзқарасын ескере отырып анықталады. Бұл әдістеме салыстырмалы зерттеулерді, салыстырмалы-тарихи-типологиялық, жүйелік әдістерді және талдау әдісін ескереді.

Мақаланың негізгі тұжырымы-тұңғыш қазақ фольклоршысы Ш.Ш. Уәлиханов журналистиканың бастауында, очерк шебері ретінде айтылады. Оның "Жазбаларын...", "Ескертулерін...", "Очерктерін..."терең зерттеуді қажет етеді: ол қазіргі ауызша теория мен әлемдік фольклордың көптеген бағыттарын алдын ала болжаған. Бұл көрегендік идеялар оның көпғасырлық Дала білімінің бірегей құндылығын айқын сезінуіне негізделді, оның маңызды бөлігі Солтүстік Кавказ, оңтүстік Сібір, Қазақстан және Орта Азия түріктерінің ұлы ауызша эпосы мен фольклоры болды. Сөз өнерінің біртұтас, біртұтас Дала дәстүрі алғаш рет оның шығармаларында өзінің барлық жанрлық және түрлік әртүрлілігінде пайда болды. Түркі халықтарының фольклоры мен сөз өнерін талдауға деген осындай біртұтас тарихиэтнографиялық көзқарас ауызша теория үшін де, әлемдік эпосты зерттеу үшін де практикалық және әдіснамалық маңызға ие.

Түйінді сөздер: жанр, Пэрри-Лордтың ауызша теориясы, дәстүр, формулалық стиль, ауызша өнер, Дала білімі, жанрлық форма.

\author{
Жанабаев К. ${ }^{1}$, Тургенбаева А.Ш. ${ }^{2}$, Ислямова У.А. ${ }^{3}$ \\ ${ }^{1}$ Казахский нацииональный университет имени аль-Фараби \\ ${ }^{2}$ Казахский национальный университет имени аль-Фараби \\ ${ }^{3}$ Казахский национальный университет имени аль-Фараби, \\ Казахстан, г. Алматы, ovlur1963@mail.ru
}

\title{
Ч.Ч. ВАЛИХАНОВ О ЯЗЫКЕ И СТИЛЕ ТЮРКСКОГО ЭПОСА
}

\section{Аннотация}

В статье говорится о научном вкладе Ч.Ч. Валиханова в тюркское эпосоведение, об изучении им эпической культуры тюрок Центральной Азии, Южной Сибири и Северного Кавказа. Основное место в ней посвящено вопросам языка, стиля и жанра эпоса тюркских народов, их поэтическим формам и их искусству слова.

Цель статьи - раскрыть взгляды и методологические подходы ученого в свете актуальной устной теории Пэрри-Лорда, выявить их перспективность и продуктивность.

Практическая ценность статьи исходит из научной эффективности трудов и идей ученого в анализе им устных поэтических форм фольклора, стилистики и эстетики.

Основной метод Ч.Ч. Валиханова - целостный, то есть взгляд «изнутри самой традиции» в ее живом процессе. Этот метод не исключал сравнительно-исторического, типологического, системного метода, метода анализа и выявил большие перспективы в научном исследовании устного эпоса тюркоязычных народов.

Основной вывод настоящей статьи - первый профессиональный востоковед, этнограф, историк, лингвист Ч.Ч. Валиханов выступает основоположником классического тюркского эпосоведения, первым собирателем и оригинальным комментатор его лучших образцов. Он гениально предвидел многие направления современной актуальной устной теории и мировой 
фольклористики и глубоко понимал уникальную природу древнего Степного знания, могучего устного эпоса тюрок Северного Кавказа, Южной Сибири, Средней и Центральной Азии. Впервые эта целостная эпическая тюркская традиция описана им во всем жанрововидовом богатстве. Историко-этнографический подход ученого к анализу эпического искусства тюркских народов имеет ценное практическое значение для устной теории и гуманитарных наук.

Ключевые слова: поэтическая форма, устная теория Пэрри-Лорда, традиция, формульный стиль, тюркский эпос, Степное знание, начальные основания.

1. General characteristics. Of the 19th-century orientalists who studied the Steppe, he was the only one who correctly appreciated the beauty and unique richness of the ancient nomadic culture, and through the laws known to science at that time, he revealed common ways of developing the epic tradition, forgotten by the Modern European peoples. He foresaw many directions of the Turkic and world modern folklore studies.

But the visionary ideas of the scientist were based on a solid foundation, on the Steppe knowledge, part of which was the oral centuries-old epic of the Turks of the North Caucasus, Central Asia and Southern Siberia. He was clearly aware of the ancient origins of the Turkic language and the epic. Unified in its development, the oral tradition of the Turkic nomads first appeared in the works of the scientist not only in all its genre-specific richness and structural originality, but also "from within the tradition" and with his brilliant use of advanced scientific methods of Oriental studies. Such a method - "a look from within the tradition" - has an important and promising significance for folklore studies, epic studies, and the art of speech.

Today, the main theories of the origin of the epic prevail in the world folklore. All of them are presented in the book by E.M. Meletinsky "The Origin of the Heroic Epic". E.M. Meletinsky described the schools in detail, listed the main representatives of these schools: historical (K. and M. Chadwick); neo-mythological - English (F. Raglan), Dutch (Jan de Vries), French (Sh. Otran, E. Miro, J. Dumezil). Among the theories that are subject to a thorough analysis of the Russian scientist, there is also an oral theory of American researchers of the twentieth century, M. Parry and A. B. Lord, which, despite the criticism of various national schools of folklore and epic studies, still has not lost its productivity and methodological value. For our research, it is the point of criticism where E. M. Meletinsky notes that even A. Lord, who deduces "the poetic style from the poetic technique of oral creativity, does not doubt the mythological origin of the content of epic formulas" (Meletinsky, 1963:12). But we have no doubt that M. Parry and A. Lord is on the right track: the traditional language and style of the Kazakh oral epic, its poetic forms fully live with their ancient formulas and formula combinations - the main means of oral-stylistic technique, which, in our opinion, goes back to the initial foundations of the epic, to the phenomena of the suggestive order: archaic myth, rite and ritual. Here it is appropriate to mention the opinion of the researcher B. Sh. Abylkasimov, who noted that in science "increased interest in the study of problems related to repetition, with such features of repetition as formality, stability of the position of words, stability of stylistic blocks" (Abylkasimov, 1984:71).

We also need the Parry-Lord method in our research, since we study the formula style and oralstyle technique in the poetry of Zhyrau of the XV-XVIII centuries. We are interested in the epic formula, its functioning, its reconstruction in the rigid metric scheme of zhyrau, and most importantly, the law according to which, being the "main structural unit of the oral text", the formula always and invariably has its permanent position, appearing in the form of a wide variety of stable lexical units" (Zhanabaev, Akberdy, 2017: 4).

As for the book "The Storyteller" by A.B. Lord: it sets out the main provisions of oral theory, and, according to the authors of the Preface, it has long been a classic. But neither this book, nor the most oral theory, could the Kazakh scientist of the nineteenth century know. American folklore itself reached these limits only in the first half of the twentieth century. But due to his deep knowledge and understanding of the specifics of the steppe singing art, Ch.Ch. Valikhanov put forward a number of ideas that are important for the oral theory that studies the art of the word. It is 
also important that the Kazakh researcher was at the very core of the performing process, knew it from the inside, initially and directly as a practitioner-folklorist. He first recorded famous epics from the mouths of nomadic singers, presented the main examples of the genres of oral creativity of the Kazakhs of the XIX century, described in detail their forms, goals and practice of performance.

Russian scientists of the late XIX - early XX century noted the multifaceted talent of Ch.Ch. Valikhanov, his contribution to science, and his special importance for Oriental studies. They "unanimously recognized in his person a phenomenal phenomenon and expected from him great and important revelations about the fate of the Turkic peoples" (Veselovsky, https://znanija.com/task/31293246). Well aware of the Greek tradition, he also touches on the Homeric epic in his articles, revealing the general patterns of the oral practice of the singersstorytellers. In them, he covered the issues of authorship and performance, the origin of the epic and its historicism, the ritual and mythological origins of the epic and lyrics, and other relevant aspects of Homeric studies.

The book "The Singer of Tales" has not lost its constructive ideas, and as the authors of the Preface noted, it is extremely important for the study of epic traditions, both Western and eastern. The main object of observations of M. Parry and A.B. The oral-style technique and the formula style became the Lord of steel. They explained the stereotypical nature of the epic style, in particular the epic of Homer, by the "specific mechanism" of song composition, by the singer's memorization of them (Preface, https://vk.com/wall209887955_2131).

This theory is also extremely interesting and useful to us, since formulas and formulaic expressions were found not only in Western European epics, but also in Russian epics, and in the Kyrgyz epic "Manas" and in Kazakh fairy tales. Particularly interesting is the formulaic style of oral speeches of the Kazakh XV-XVIII zhyrau centuries, which use zhyr as a traditional form of heroic tales and as a form of philosophical and didactic songs (tolgau). Culturologist A.B. Naurzbayeva notes that the phenomenon of zhyrau "arouses the interest of researchers from various scientific fields due to its complex nature and inherent polyfunctionality" and various disciplines have interpreted this object from the position of their methodological foundations (Naurzbayeva, 2017: 279).

\section{Relevance.}

1. Appreciating the experience of his predecessors: P. Pallas, N. Rychkov, I. Georgi and other researchers, Ch. Ch. Valikhanov for the first time approaches the verbal art of the Turkic-speaking peoples not only as a source of history and ethnography, but as a source of folklore, epic studies, philology, as an exceptional aesthetic and spiritual value of the Turks. So, speaking about the Nogai epic, the scientist notes: "Nogai legends and refer to the end of the XIV, XV and XVI centuries. These legends have an epic character and are sung in rhymed verses and therefore belong to the field of folk, oral literature. They are remarkable as expressions of the national spirit, concepts, customs, mores, and way of life, they are also remarkable in philological terms and are not devoid of historical interest" (Valikhanov, 1986: 287).

2. Today, the nostratic theory of languages and cultures, the search for common ancient origins of the proto-language, is also relevant in science. The homeland is assumed to be Central Asia, the Ural-Altai cultural and linguistic substratum. A look at the epic culture "from within the tradition", knowledge of the Turkic and European languages, first-class training, led the Kazakh scientist to the newest method at that time, comparativism. Thus, in the" Essays of Dzungaria " the author writes that he "was struck by the identity of their motives with the motives of the works of this kind of European peoples, especially the Slavs..." (Valikhanov, 1986: 273). Identifying the identity of the motifs of Kazakh, Kyrgyz, Mongolian, Western European and Slavic epics, the scientist was close to the German mythological school with its search for a common homeland of language, myth and epic. This theory was partially reflected in the works of subsequent Kazakh folklorists and Turkologists: A.H. Margulan, A.S. Amanzholov, E.D. Tursunov, and especially S. Kondybai, etc.

3. With regard to the oral theory of Parry-Lord, let us explain: the central point around which all the theoretical issues of Kazakh epic studies are concentrated is the zhyr, or jir, as it is called in the old way by Ch.Ch. Valikhanov, an epic song that was sung to kobyz in the form of a recitative 
from ancient times. The singer who performed it was called zhyrau, and the song is so named after the form of zhyra (a verse of 7-8 syllables).

The valuable observations of Ch.Ch. Valikhanov on the poetic structure of zhyr today answer the questions of the genesis, formation and specifics of verbal and musical culture, the performing nature of storytellers, and many aspects that interested American researchers M. Parry and A. B. Lord, in particular: how the singer composes and how he assimilates, how he conveys his song (Lord, https://vk.com/wall209887955_2131).

Exploring this verse form and epic genre, we are sure that zhyr is a code, a folded text of centuries - old Steppe knowledge, which has preserved the structure of ancient poetic thinking, dating back to archaic myth, rite and ritual, that it is a source for other genre forms of both epic and lyric - epic order (for example, maktau, arnau, osyet, zhoktau, etc.). time for a genre transformation: "jilav is usually invented by women and very often improvised. The size is used the same as in the jir" (Valikhanov, 1986: 238). And gives examples of famous jilavas.

\section{The purpose and object of the study.}

Such a "view from within the tradition itself", a holistic view of the scientist on the poetic language, on history, actualized the purpose of the study: to identify the novelty, relevance and productivity of the scientific ideas of the Kazakh scientist of the XIX century in the light of the modern oral theory of Parry-Lord, to which today the attention of many folklorists of the world is drawn. Ch.Ch. Valikhanov proceeded from the primacy of stable ancient forms of folk poetry as an enduring value. He recorded the most important historical changes in the genre structure of the epic and folklore of the nineteenth century. Thus, analyzing the article "On genre forms of Kazakh folk poetry", S. Negimov revealed its main advantage-consistent historicism: "It is noteworthy that the author, with his characteristic methodological sensitivity, first drew attention to the historical conditionality of the genre, rhyme and content design of the traditional poetic heritage of nomads" (S.Negimov. https://cyberleninka.ru/article/n/folklornye-materialy-v-tvorchestve-ch-ch-valihanova). Therefore, zhyr, as we said above, both as an ancient epic form and as a verse structure of the song itself, became the starting point, the main object of observations of Ch.Ch. Valikhanov, and this, in our opinion, is of valuable importance for the oral theory of Parry-Lord, for understanding the general laws of the development of the epic.

\section{Methods and scientific and theoretical basis of the research.}

Since the study of the oral epic and folk-poetical tradition of the nomads can shed light on many problems facing folklorists, most of them are only addressed to their national epic and in their entirety do not even imagine how useful the oral theory of Parry-Lord can be in combination with the ideas of Ch.Ch. Valikhanov. We have made an attempt to combine the achievements of these two outstanding schools, which together solve some important problems of the epic, such as the study of eposogenesis, poetic form, the role of formulas in the epic tradition and its significance for the reconstruction of ancient language and myth, etc. After all, it is precisely because of the specifics of centuries-old and continuous development that the oral epic culture of the nomads was able to preserve important patterns, properties and signs of world epic development that were lost by the settled peoples in the flow of history. The method of Parry-Lord's oral theory, especially the formula style, oral-style technique and formula grammar, as well as the holistic approach "from within the tradition itself" by Ch.Ch. Valikhanov, is, in our opinion, today the most productive way for disciplines studying various aspects of world folklore and epic studies, as well as for "understanding and reconstruction of the spiritual universe of nomadic society" (From the authors, 1993: 5).

In Kazakh epic studies, the methods of oral Parry-Lord theory are successfully used by B.Sh. Abylkasimov, U. Akberdi, Zh. Bekturov, T. Esembekov, K. Zhanabayev, Sh. Ibraev, S. Negimov;

The scientific and theoretical basis of this study was also the work of:

a) Kazakh scientists: S. Akatayev, A. Amanzholov, M.O. Auezov, A. Zhaksylykov, Mukhambetova A., A. Naurzbayeva, O. Nurmagambetova; 
b) Russian scientists and CIS scientists: Grinzer P., Gura A., Zhirmunsky V., Meletinsky E., Maltsev G., Milevsky T., Revunenkova E.;

c) foreign specialists in oral theory: Arens W., Bailey J., Bascom W., Baumi F., Bridney D., Dundes A., Finnegan S., Foley J., Clifton A., Kongas E., Kunst T, Levinton G., Lord A.

The historical and genetic method of Ch.Ch. Valikhanov, used by him in order to study such a unique phenomenon as Steppe knowledge, and in his system - the oral epic culture of nomadsallowed us to highlight a number of theoretical problems that are of current importance both for modern epic studies and for the oral theory of Parry-Lord itself. Only one passage from" Manas " fully shows how valuable the entire epic is as a source of research on the history, culture, life and worldview of the Kyrgyz people.

Ch.Valikhanov was the first of the contemporary orientalists to also apply the comparative method in the study of oral poetry of nomads: The scientist begins - "The propensity for poetry, especially for improvisation, distinguishes all nomadic races". The poetic mind of the Bedouins and their improvisational poets are well known to Europeans... The same phenomena are represented by the Mongol-Turkic generations...". He compares the way of life of the steppe nomads of different regions, pointing out the reasons for this similarity and touching on the nature of the influence of nature on man (Valikhanov https://shoqan.kz/incompleted/works_zametki_po_istorii/).

A large place in the legacy of Ch.Ch. Valikhanov is occupied by works of a comparative typological nature. He studies the oral tradition - epos, folklore and mythology-not only on the basis of the Turkic-language material, but also with the help of the narrative traditions of Eastern and European peoples. The idea of studying the history and culture of the people through a living process sounds convincing in the mouth of a scientist. Entering into a polemic with researchers who proceed from the presence of a written fact, a document confirming the historical reality of an oral legend, the scientist suggests the following: "If the poetic legends of Homer and the legends collected according to rumors by Herodotus have any historical merit, if every distorted, fabulous tradition is based on an incident and truth, then there is no doubt that the positive and consistent legends of the Kirghiz, their way of life, customs and customs are modern, they reflect the way of life of their ancestors and, when compared, agree in everything with historical indications, can have a historical meaning" (Valikhanov, https://shoqan.kz/incompleted/works_zametki_po_istorii/). Relying on the data of ethnography and folklore, especially on the legends of the people, the scientist claims that they remain the source by which the reconstruction of events and phenomena of the historical life of the people is possible. Here, as the Kazakh cultural critic M. M. Auezov subtly and ironically remarked, " everything depends on what exactly we release from the content of the epic (Auezov, 1993:38).

What else is valuable to us for such a holistic approach?

The role of the oral legend of the nomadic Turks is particularly important here. Through the analysis of names, facts, and events reflected in poetic speech-psychological, ethnographic, and other features-we have come to understand that the traditional oral text, with its basic lexical and semantic composition, unchanging structure, stability of forms and formulas, and unique ethnographic and psychological details, is of particular interest to oral theory.

Holistic approach Ch.Ch. Valikhanov gives us a vision and study of an object or phenomenon, first, in the unity of form and content, in the unity and continuity of oral tradition, word and music, and sometimes pantomime (the so-called syncretism); secondly, in their historical sequence, continuity, development and change within the framework of the structure: teacher-student (atadanbalaga): and third - in their utilitarian, socially useful sense, didactic and edifying function (aesthetic, ethical, cognitive).

In the holistic analysis of the text of oral poetry, there is a need for a structural-semantic method, when the epic, a fragment of the epic or any part of it acts as a semantically and functionally significant unit of the whole, as an element of the general process of generating or performing an epic text. Here, a separate class of formal-structural elements, different levels, and 
any aspect of an oral story can be studied: sound repetition, lexical or syntactic anaphors, etc., which affect the style and genre of an oral utterance.

In his argument, Ch. Valikhanov proceeds from a view from within the tradition itself and such important features as "positive and consistent " legends, which "when compared in all respects consistent with historical indications", "can have historical significance".

Let us consider such a feature of a folk epic as "successive tales".

Unlike all European and most Eastern sedentary peoples, Kazakh nomads have preserved a continuous centuries-old oral continuity of information transmission. This is a kind of Steppe knowledge, an oral tradition of thousands of years, and it is the collective memory of specific clans and tribes about the events of their ancestors and those who know their heroes, that is, their kind and tribe. Consistency as a term is that the steppe people know all their leaders, batyrs and outstanding akyns-performers not only up to the seventh generation, as evidenced by their oral traditions (shezhire) about the history of clans and tribes, which every adult and the entire tribal (tribal) collective knows unmistakably, but also much further, according to which the entire powerful family tree is also unmistakably built. Therefore, Ch.Ch. Valikhanov writes: that there is no doubt that the epic, oral tradition, folklore and ethnography can be a living source of research. Akataev calls this sequence continuity. "This continuity of culture-the author writes - and at the same time its natural processes can be witnessed by the chronological dynamics of the sources themselves (Akataev S. 1993: 7).

The methodological principle of the Kazakh scientist comes from his awareness of this original continuous tradition, a specific school of Steppe knowledge. In ancient times, it served as a myth-a story about the totem-the patron saint of the family, and in the course of the development of sociohistorical life due to demythologization and desacralization, it became an oral epic tradition, but preserved important sacred elements (for example, the cult of ancestors, Aruahs, the worship of fire and pagan rituals, traces of Tengrianism, etc.). The intellectual part of this grandiose Steppe knowledge was the oral steppe epic of nomads. In "Forms of Kazakh folk Poetry" Ch.Ch. Valikhanov also identifies another important feature that is important for our judgment - "positive legends", describing them as:

a) oral poetic works of "purely popular mind, determining the feelings, life and progress of the entire mass of society" (Ch.Ch. Valikhanov https://shoqan.kz/incompleted/works_zametki_po_istorii/)

b) works " poured out from the mouth of the whole people as from the face of one being»;

c) as oral works, not devoid of historical, philological, psychological interest, where instead of a fact, a written document, the "whole mass of society", the whole people as "one person", recreating in the epic all its history and all its ethnographic appearance and grandiose past. The language of tradition, which has preserved this fund of knowledge, becomes an important source for studying the historical life of the clan and tribe. For a Kazakh educator who studies folklore and epics, this was not a surprise. It was realized by him as a given, realized "from within the tradition" as a unique phenomenon of an original nomadic culture.

Ch.Ch. Valikhanov also used the method of direct recording. Directly from the mouth of the performers, he recorded such valuable monuments of Kazakh and Kyrgyz oral epic culture as an excerpt from the Manas "The Death of Kuketai Khan and his Wake" and the epic "Kozy-Korpesh and Bayan Slu".

His followers: M.O. Auezov, A.H. Margulan, A.Abylkasimov, S.Adzhigaliyev, A.Amanzholov, R.Berdibayev, S.Negimov, E.Tursunov used other, different methods, but the main one was historical and genetic, which allowed to trace the processes of origin, the peculiarities of the formation of oral and musical folklore phenomena and to reach deep generalizations concerning various aspects of the Kazakh oral and poetic culture and Steppe knowledge.

The comparative method, which has now become traditional, is also of great importance for oral theory. But it was first used by Ch.Ch. Valikhanov in the XIX century. At that time, comparative studies were still in its infancy and had not been widely developed.

The main provisions of the study and the novelty: 
1. To show the role of $\mathrm{Ch}$. Ch. Valikhanov as the founder of the Turkic epic studies and scientific methods in the spirit of the oral theory of Parry-Lord;

2. Based on a critical review of Kazakhstan and foreign studies, to reveal the scientific talent of Ch. Ch. Valikhanov in foreseeing promising directions in the light of the oral theory of Parry-Lord;

3. To investigate the peculiarity of the Kazakh scientist's holistic approach to the study of the Turkic oral epics as part of the great Steppe knowledge: the antiquity of poetic forms and genre structures of the oral traditional text, based on continuity, on the tradition of transmitting continuous centuries-old Steppe knowledge, an important part of which was the oral epic culture of the Turks of Southern Siberia, Central Asia, the Crimea and the North Caucasus. It has been preserved in its traditional form thanks to the formulaic style and oral-stylistic technique;

4. To reveal the influence of the scientific methodology of Ch.Ch. Valikhanov on his followers in the field of oral theory, proceeding from the fundamental principles of the oral theory of ParryLord;

5. To identify the perspective significance of the ideas of Ch.Ch. Valikhanov and Parry-Lord for the study of the Kazakh and world art of speech.

Discussion. As the authors of the preface to "The Singer of Tales" note: "The book of A. B. Lord ... formed an epoch in the history of the study of the epic" (Lord, https://vk.com/wall209887955_2131). We also have no doubt about the installation of M. Parry and A. Lord, that "epic formulas have a mythological origin" and we believe that this is the main point of the Ameriacan authors, that they indicated it correctly, especially if we study this problem on the ancient Kazakh language material, using the "view from within the tradition itself" and the valuable method of Ch.Ch. Valikhanov.

We are also clear about the valuable significance that A. Lord deduces about "the profession of the epic storyteller and about the contribution made by the storyteller from "the most ancient times to the spiritual development of mankind" (Lord, https://vk.com/wall209887955_2131). But Kazakh and Kyrgyz nomadic epic singers are interesting to us not only from this side. Their oral texts are "consistent", that is, they have a sign of continuity, that is, they have retained a direct connection with their ancient initial foundations: archaic myth, rite, ritual, and even further and deeper - with a nonverbal way of explaining the world and its structures, the first poetry, if by poetry we mean everything that was before the myth as a whole picture: suggestive magic, mimesis, throat, and then jaw imitative singing, up to the comprehension in early shamanism of other possibilities of selfexpression (alliteration and assonance), known to us from the ancient Turkic and modern oral traditions of the Altai, Siberian, Turkic-Mongolian peoples, who preserved a large corpus archaic elements. The above directly relates to the ability to preserve, use and transmit archaic techniques and means of oral technique, genre forms, as well as formulas and formulaic expressions that form the backbone of the formulaic style, called in oral theory "formulaic grammar". These technical means, especially formulas and formulaic expressions, function only within the framework of a poetic meter, for example, zhyr: here is an example of its scheme: $1+3+3$ :

\section{Марғасқа жырау, XVII век}

Хан емессің, қасқырсың,

Қара албасты басқырсың

(БҒЖ, 1989:56).

\section{Махамбет, $\mathrm{XX}$ век}

Хан емессің, қасқырсың, Қара албасты басқырсың

(БҒЖ, 1989:181).

At present, all the formulas and formulaic expressions of oral poetry of zhyrau of the XVXVIII centuries are recorded and grouped by signs, properties and functions. A frequency Dictionary of formula expressions of the epic language of Zhyrau is being compiled. Now it is extremely important to investigate the mythological history of their origin and the specifics of their functioning. This is important for finding their mythological source and understanding the laws of oral generation, execution, and transmission of the epic text. We believe that the most initial, 
nonverbal, epic was a universal cosmic representation, a story-myth and the teaching of the universal kinship of man and the forces of nature, as A.F. Losev and Yu. Borev write. The nonverbal epic is the source of canons, magic teachings that have come out of the game, mimesis, and imitation. This is the time of fixing the first teachings, fixing the first signs and techniques: the addition of archaic structures and elements of the tribal and tribal rite and the rules of ritual. The teaching is based on various types of repetition and circling (around a fire, a rock, a mother birch as a reflection of the universal circling of the stars and the sun, the seasons).

Sh. Ibraev in the book "Epic formulas and poetic means "Kitabi dedem Korkut", speaking about the traditional formality of the language as the main feature of the epic, refers to $\mathrm{V}$. Radlov, who explains the memorization and oral transmission of heroic legends by the presence of readymade traditional language formulas and various repetitions. This "idea" was developed in more detail by the American scientists M. Parry and his follower A. A. Parry. Lord, who put it forward as a theory (Ibraev, 1989, p. 71).

The actual question of the oral theory of M. Parry and A. Lord, the question of the process of execution. Here we proceed from an understanding of the environment in which the performer, the creator of the text, acts. Nomadism is the place where the epic reigns. The epic belongs to everyone, the absolute majority knows it. This majority itself is the musical and singing environment-the source of the formation of the performer. And the singer himself is a structural element of this environment-the semiosphere, where everyone sings and plays, and performs the epic.

Kazakh nomadism of the middle of the XIX century, the time of Ch.Ch. Valikhanov is a special musical and poetic environment, which can be described as absolute without any idealization. This environment was actually formed from time immemorial and lasted until the late Middle Ages and the beginning of the twentieth century. For many centuries, it was a powerful cradle of the musical and poetic art of the nomads, which created bright and original oral samples of the epic, and put forward brilliant performers: poets and composers. Therefore, the famous orientalist traveler, a friend of Ch.Ch. Valikhanov, G.N. Potanin remarked with delight: "The whole steppe sings!" and described this creative environment: here everyone sings and plays: boys and girls, boys and girls, adult women and men, and they all know and love legends, legends. The vast majority of these amateurs and performers, including boys and girls, memorize and repeat whole plots and vivid fragments on each occasion. They often try themselves in tough poetic disputes (aitys), they diligently learn oral skills from zhyrau, Akyns and biys. So the environment creates a similar singer. Here is the wise old akyn Aronuly Suyumbai, who enters aitys with the six-year-old Zhambyl, blesses him, gives him his instrument, and wishes him guidance in the difficult art of aitysker.

Of course, among the performers of zhyrs, legends, legends and musical pieces-kuys, there is one who performs with a greater or lesser degree of talent than others, but here only the people act as an expert and the best connoisseur of traditional themes and plots, a connoisseur of stable turns, traditional formulas, a zealot of the laws of oral and stylistic technique. The people remember all the events in verse. Dozens and hundreds of events and stories are kept in the head of a talented zhyrshy, who is listened to in this environment. All events are performed in the form of a zhyr (7-8 syllables), fastened with traditional formulas or formulaic expressions. Thanks to these formulas and repetitions of various types, they are easily learned within the same zhyr: $4+3$, or: $1+3+3$ :

Есет би , 19 век

Мен, мен едім, мен едім,Қатарға салсаң қайыспас Қас қара нар мен едім...

(БҒЖ, 1989:167).
Махамбет, 19 век

Мен, мен едім, мен едім,Мен Нарында жүргенде Еңіреп жүрген ер едім... (БҒЖ, 1989:191).

All these zhyrs and traditions, both in their external form and in their internal structure, send us to a single archetype-source: the generic text-a rite in honor of the patron spirit of the family, the 
canon. In traditional Kazakh society, they act in the form of a teaching, a covenant that comes from the ancestors. Here is an approximate structure of such a canon of the genre of zhubatu-solace, where the epic formula acts as a thematic center and serves as a refrain:

\author{
Үмбетей жырау, 18 ғ. \\ Ей, Абылай, Абылай, \\ Сөзімді тыңда тағы да-ай! \\ Өзіңмен біраз жасы үлкен, \\ Дөмпеш таудай басы үлкен, \\ Жасында боллған сырласың, \\ Үлкен де болса құрдасың. \\ Сексеннен аса бергенде \\ Қайрылмас қаза келгенде, \\ Батырың өлді - Бөгембай! \\ (БҒЖ, 1989:79).
}

\section{Бұқар жырау, 18 ғ.}

Қайғырмаңыз, ханзадам, Келмей тұр ауызым айтарға,

Батырың өтті Бөгембай!

Еңбек қылған ел үшін, Жауда кеткен кек үшін, Қазақтың абырой-арына Сарып қылған бар күшін, Қайыры болсын халқыңа, Сабыр қыл, ойлап келмесін, Қарияң келіп жырлап тұр Еңбегі сіңген ер үшін, Батырың өтті Бөгембай... (БҒЖ, 1989:100).

This verbal epic speech is represented by various visual and expressive means, a wealth of consonances at different levels, sound repetition, various types of anaphors, alliterations, assonances, etc.), the genetic origin of ancient magic, a ritual in honor of a deceased ancestor (formerly a totem, then a leader with signs of idealization and mythologization, and now the hero of the epic). This oral speech of the performer is remembered by the listener due to the effect of a clear rhythm and consonance, stable formulas, formula combinations and repetitions that perform a utilitarian (mnemonic) function. As the listener's memory is preserved, the traditional butter is easily remembered due to the equal rhythmic-syntactic segments that are constantly played by the singer.

\section{Бұқар жырау, 18 ғ.}

Бұл, бұл үйрек, бұл үйрек, Бұл үйректей болыңыз...

(БҒЖ, 1989: 94).

\section{Бұкар жырау, 18 ғ.}

Бұл, бұл үйрек, бұл үйрек, Бұрылып ұшар жаз күні...

(БҒЖ, 1989: 101).

Contribute to a strong influence on the listener and the redirect, and verbal rhyme and monorym, the place of which is always determined at the end of the verse and is always expected by the listener. Folklorists noted that during the reign of the epic art of the heroic singers of zhyrau, that is, from the middle of the XV - to the middle of the XVIII century, tolgau, recitative utterance in the form of philosophical or edifying-didactic reflection, gained a great place in the Steppe knowledge. These short-form poetic utterances also preserved the verse form of the ancient zhyr: undeu, osyet, koshtasu, bata, kargys, etc. But the ancient zhyr, consisting of seven or eight syllables, so necessary for the existence of oral tradition and Steppe knowledge, depending on the accent and intonation, on the target attitude of the singer and the genre nature, shows a completely different degree of expressiveness, from contemplation and meditation to rapid expression.:

Асан Қайғы, XV ғ., philosophical lyrics

Таза мінсіз асыл тас

Су түбінде жатады,
Махамбет, XIX ғ., battle marching song

Ереуіл атқа ер салмай,

Егеулі найза қолға алмай, 
Таза мінсіз асыл сөз

Ой түбінде жатады.
Еңқу-еңқу жер шалмай..

(БҒЖ, 1989:180).

(TMAT, 2014:11)

Formulas and formula combinations carry in their semantic cores subtexts, deep meanings, the concentrated meaning of the idea and the thoroughness that give the whole oral utterance a philosophical or patriotic, heroic character. For example, in the marching song of Makhambet, the researcher Zhaksylykov notes a sign of expression, numerous repetitions, alliterative rhythms, monoryms, anaphora, redifs, expressively aestheticizing "the idea of movement, offensive, attack, stormy invasion" (Zhaksylykov, 2013: 241-312).

That is why, turning to oral practice every time, the singer hones his skills at every opportunity. In a competitive singing environment, he quickly gets used to improvising on a given topic, and sometimes thinking through and memorizing the song in advance before the upcoming fight with another akyn. It is important for Akyn to master the poetic form, oral stylistic technique, verbal and artistic means, theme, richness and various types of rhymes. All this powerful, flowing mass of stories, legends, epics, lyrical genres and epic motifs, living in a single rhythm among the people, makes up the singer's substantial arsenal, his intellectual power, his poetic appearance. The singer creates and performs an epic tale of the past as a reliable narrative about his tribe, about his ancestors, about the people. Speaking of historical knowledge, his song is reproduced in the same form in which it was sung by his ancestors-storytellers, and among the ancient Greeks - even gods, demigods and heroes, and among the archaic Turks-bucks and shamans, ritual intermediaries.

In such an absolutely singing, musical and verbal environment, different types of carriers of the Kazakh oral and poetic culture are formed: zhyrau (creators of the epic), akyns (akyns - lyrical and performers of democratic themes), saly and sary (lyrical singers of the theatrical plan, eccentrics). These singers represent different social groups and political image. Each of them has its own genre and its own thematic repertoire. But any of these performers will not be able to compose, assimilate and transmit their songs outside of a single tradition, and they have nothing but the steppe poetic tradition. To this opinion, writes A.B. Lord, came and M.Parry (Lord, https://vk.com/wall209887955_2131).

"It is even more amazing," continues Ch.Ch. Valikhanov," that in all the most remote parts of the steppe, especially the poetic sagas, are transmitted in the same way and when compared were literally identical, like the lists of one manuscript. Strange as this incredible accuracy may seem from the oral sources of a nomadic, illiterate horde, it is nevertheless a valid fact that cannot be doubted. " https://vk.com/wall209887955_2131).

Here the opinion of the researcher $\mathrm{Zh}$. Zh. is valuable. Bekturov, who expressed a deep judgment that the consolidation of ancient words and images in the text was primarily promoted by the poetic form of the works itself (obviously the effect of the so-called "law of formality", developed in the works of Parry and Lord (Bekturov, 1989:48). We explain this "real fact" by the tradition and the action of the oral technique that M. Parry and A. Lord wrote about. The whole process of creating, performing and transmitting oral epic works is a tradition, an oral art of the centuries-old technique of storytellers of one medium. The more talented one strives for competition, for even greater skill, for mastering an even greater arsenal of oral-stylistic epic techniques, for his talent to be recognized and approved by the main expert, the best expert in form, content and technique - the people.

Another important condition for better memorization and better performance of an oral poetic text: for national recognition, the akyn must participate in poetic competitions, fights-aitys with akyns of other families always or almost always. Like a batyr in battles, in fights, an akyn creates a name for himself, and then repeatedly confirms his right to be the best first akyn (bas akyn), since 
everyone sings in the nomad region, since the whole nomadic environment creates and there are enough akyns. It is necessary to be the best in this singing environment: at large gatherings or during holidays and tribal and tribal events, the clan puts forward the best singer for a fight-aitys with an akyn of another kind or tribe. And here the matter is already in the honor of the akyn himself, who defends the honor of the family. This is a strong enough motivation for constant creative self-improvement. It plays a major role in the moral, psychological and intellectual training of the singer in a competitive environment. Hence the constant exercises in the art of memorizing and quoting.

\section{Conclusions}

1. The role of Ch.Ch. Valikhanov has already been appreciated by the contribution he made to epic studies. In his articles, we still find answers to such questions of the oral theory of M. Parry and A. Lord, as the question of authorship and performance, about the nationality of the epic, about the nature and meaning of oral-stylistic techniques and the formulae of poetry, and most importantly - about the process and nature of performance. These answers are found in the following works of the Kazakh scientist: "On the forms of Kazakh folk poetry", "Essays of Dzungaria", "Notes on the history of South Siberian tribes", "Kyrgyz genealogy", "Traces of shamanism among the Kyrgyz".

2. Ch.Ch. Valikhanov, well aware of the Turkic languages, the steppe oral tradition and the achievements of contemporary classical Oriental studies, for the first time in science used such a method of research, which we have designated as a view "from within the tradition itself". This view contributes to a more thorough and more effective study of the national specifics and structure of the oral epic. Ch.Ch. Valikhanov used both historical and ethnographic, and comparativehistorical, and comparative-typological methods, acting as the first comparatives in science and largely predetermined the directions of modern sciences. By that time, comparative studies were still in its infancy;

3. The Kazakh scientist proceeds from the specifics of the oral epic as a significant component of the ancient Steppe knowledge. From the research of the scientist, we conclude that this oral epic culture of the Turks was preserved in its pure form thanks to the epic environment, steppe teaching, oral formula style and oral-style technique.

4. The perspective significance of the ideas of Ch.Ch. Valikhanov lies in the fact that his ideas do not contradict, but significantly complement and enrich the modern oral theory of American epic scholars. Together, these two methodologies meet the challenges of modern criticism and open up new areas of research in the field of epic and folklore, and especially in the field of the genesis of forms, the search for a common homeland of myth, epic and poetic word.

5. From the works of the Kazakh scientist, it follows that the oral knowledge of nomads is a single and integral in its development, always and everywhere functioning musical and verbal tradition, in all its genera, types and genres. This tradition is formed by the ancient environment the main condition for the formation of singers. This is the ideal source of the life of the steppe epic, its origin, singing, memorizing, and transmission. In parallel with the process of memorizing and memorizing, in the course of practice, the technique of oral performance is also honed from time to time, the complex of oral-style technical means and techniques and the "formula language" are enriched.

6. Thus, the first Kazakh orientalist Chokan Valikhanov made an invaluable contribution to epic studies, to modern oral theory. Its rich scientific and cultural-historical heritage is of lasting importance for the Turkic and world epic studies, for the spiritual revival of the Turkic-speaking peoples.

Список использованной литературы:

1. Абылкасимов Б.Ш. Стилистические приемы и средства в жанре толгау. В кн.: Жанр толгау в казахской устной поэзии. Алма-Ата: Наука, 1984. 120 с. 
2. Акатаев С. О специфике культуры кочевья. В книге «Кочевники. Эстетика: Познание мира традиционным казахским искусством». - Алматы: Гыльым, 1993. 364 с.

3. Асан Қайды. Таза мінсіз асыл сөз. Құрастырушы Е. Тұрсынов. Алматы: Алматы kiman басnасbl, 2014. 112 бб.

4. Ауэзов М.М. Энкидиада: к проблеме единства миров кочевья и оседлости. В кн.: «Кочевники. Эстетика: Познание мира традиционным казахским искусством». - Алматы: Гылылм, 1993. 364 с.

5. Бектуров Ж. K характеристике лексического и образно-семантического фонда памятников казахской поэзии XV-XVIIвеков. В кн.: Исследования по истории и семантике стиха. Сборник научных трудов (меджуведомственный). Караганда: издательство КарГУ, 1989. $120 \mathrm{c}$.

6. Бес васыр жырлайды. Құрастырушы М.Мавауин. Алматы: Жазушы, 1989. - 384 бб.

7. Ч.Ч. Валиханов. Очерки Дюунгарии. В кн.: Избранные произведения. М.: Наука, 1986. $416 \mathrm{c}$.

8. Валиханов, Ч.Ч. О формах казахской народной поэзии. В кн.: Избранные произведения. М.: Наука, 1986. $416 \mathrm{c}$.

9. Ч.Ч.Валиханов. https://shoqan.kz/incompleted/works_zametki_po_istorii/

10. Веселовский H., https://znanija.com/task/31293246

11. Жаксылыков А. Художественный перевод и литературный процесс. Алматы: Таңббаль, 2013. 312 c.

12. Жанабаев К., Акберды У. Поэтический Словарь языка жырау XV-XVIII веков: термины родства и сочиальная лексика. Семей, 2017 г. 288 с.

13. Ибраев. Ш. Эпические формуль и поэтические средства «Китаби дедем Коркут». В кн.: Исследования по истории и семантике стиха. Сборник научных трудов (меджуведомственный). Караганда: издательство КарГУ, 1989. 120 с.

14. Лорд A. https://vk.com/wall209887955_2131

15. Мелетинский E.M. Современные теории происхождения эпоса. $B$ кн.: Происхождение героического эпоса: ранние формы и архаические памятники. М.: Издательство восточной литературы, $1963.463 \mathrm{c.}$

16. Наурзбаева А.Б. Жырау в коммуникативной стратосфере казахского традиционного общества: дискурс-анализ. Колл. монография: Жырау: статус, функции, культура, мировоззрение. Семей, 2017. 325 с.

17. Негимов C.https://cyberleninka.ru/article/n/folklornye-materialy-v-tvorchestve-ch-chvalihanova

18. От авторов. Предисловие к книге «Кочевники. Эстетика: Познание мира традищионным казахским искусством». - Алматы: Гылым, 1993. 364 с. 19. Предисловие, https://vk.com/wall209887955_2131

List of references:

1.Abylkasimov B. S. Stili artes et opes in tolgau genus. In libro.: In tolgau genus in Kazakh ore carmina. Alma-Ata: Nauka, 1984. 120 p.

2. Akataev S. In speciali vaga cultura. In libro " Nomads. Aesthetica: Cognitio mundi traditum Kazakh es". - Almaty: Gylym, 1993. 364 p.

3. Asan Kaigy. Taza minsiz asyl soz. Kurastyrushy E. Tursynov. Almaty: Almaty kitap baspasy, 2014. $112 b b$.

4. Auezov M. M. Enkidiada: in quaestione de unitate, in secula nomadism et decisione. In libro.: "Nomads. Aesthetica: Cognitio mundi traditum Kazakh es". - Almaty: Gylym, 1993. 364 p.

5. Bekturov Zh. In characteres lexical et figuralis-semantic institutum monumenta Kazakh carmina de XV-XVIII saecula. In libro.: Studiorum in historia, et admittunt of verse. Collection of scientific libellis (medzhudepartmental). Karaganda: KarSU Publishing Casam, 1989. 120 p. 6. Bes gasyr zhyrlaydy. Kurastyrushy M. Magauin. Almaty: Zhazushy, 1989. - 384 bb. 
7. Ch. Ch. Valikhanov. Temptamenta de Dzungaria. In libro.: Delectus operum. Moscow: Nauka, 1986. 416 p.

8. Valikhanov, Ch. Ch. De formis Kazakh vulgares carmina. In libro.: Delectus operum. Moscow: Nauka, 1986. 416 p.

9. Ch. Ch. Valikhanov. https://shoqan.kz/incompleted/works_zametki_po_istorii/

10.Veselovsky N., https://znanija.com/task/31293246

11. Zhaksylykov A. Litterarum interpretatione et litterarum processus. Almaty: Tanbaly, 2013. $312 p$.

12.Zhanabaev K., Akberdy U. Poetica Dictionary of Zhyrau lingua XV-XVIII saecula: affinitate terminis et socialis vocabulary. Semey, 2017, 288 p.

13. Ibrayev. Sh. Heroicis formulas et poetica significat "Kitabi dedem Korkut". In libro.: Studiorum in historia, et admittunt of verse. Collection of scientific libellis (medzhudepartmental). Karaganda: KarSU Publishing Casam, 1989. 120 p.

14. Dominus A. https://vk.com/wall209887955_2131

15. Meletinsky E. M. Recentiorum opiniones de origine epic. In libro.: Originem heroicae heroicis: mane formae et prisca monumenta. Moscow: Libellorum Domus Orientalium Litteris, 1963. $463 \mathrm{p}$.

16. Naurzbayeva A. B. Zhyrau in communicativum stratosphere de Kazakh traditum societatis: sermo nibh. Vocant. monograph: Zhyrau: status, officia, cultura, worldview. Semey, 2017. 325 p.

17. Negimov S. https: / / cyberleninka. ru/article/n/folklore-materialy-v-tvorchestve-ch-chvalihanova

18. Ex auctoribus. Praefatio ad librum "Nomads. Aesthetica: Cognitio mundi traditum Kazakh es". - Almaty: Gylym, 1993. 364 p.

19. Praefatione, https://vk.com/wall209887955_2131 
